\title{
XXV THE IRISH AT PARIS IN 1605
}

$\mathrm{I}$ $\mathrm{n}$ his Old Irish links with France (Dublin, 1940) Richard Hayes drew together the strands of several previous articles to present a coherent and interesting narrative. He was of course much concerned with the reception accorded to the earls during their flight through France to Rome in 1607 , and also assembled material to show how in the immediately preceding years Irish influence had been increasingly felt in France, with the foundation of the college at Bordeaux in 1603 and reports of refugees at Angers, Nantes and Rouen in 1605. The two hitherto unpublished letters which are printed below amplify Hayes's further description of the condition of the largest Irish colony in France, at Paris. They are drawn from the Bibliothèque Nationale, one from the papers of chancellor Bellièvre ${ }^{1}$ and the other from the general collection of state letters covering the years $1477-1657 .^{2}$

As Hayes remarks, the colony was clustered round the site of the present Place Dauphine, on the western end of the Ile de la Cité, in an area which was then derelict as the adjacent Pont Neuf was still under construction. ${ }^{3}$ They seem to have arrived in strength in I605, as they did in the provincial towns, and our two letters illustrate the attitude of the authorities to the problems that they caused, as well as throwing light upon their condition. Both were written by the chancellor Bellièvre on 2 November 1605 , when the approach of winter was beginning to make the problem urgent. The first is to the king, and gives us a pathetic image of this little group of exiles regarded as potential marauders and possible carriers of the plague. However, as we shall see, their relief was to come from the initiative of the hotel de ville. The second letter, to the secretary of state, Villeroy, adds some interesting details; it is curious to think that these Irishmen might have formed part of that

${ }^{1}$ Manuscrits français 15894 , f. 609 .

${ }^{2}$ Manuscrits français I5540-15584; vol. I5578, f. 246.

${ }^{3}$ Old Irish links with France, p. 16. 
early French colony at Port-Royal (now Annapolis) for which Pierre du Gua de Monts was in fact recruiting that year. ${ }^{4}$

In the end nothing seems to have been done in 1605 , but the following year a major effort was made. We learn from the registers of the bureau de l'hôtel de ville that on May i 8 a special levy was being urgently made for 'l'expulsion des Irlandais'; the following day orders were issued to the municipal guards to keep watch on all the gates and ensure that all the Irish were rounded up. ${ }^{5}$ The mayor, François Miron, had seen to the preparation of a boat to carry five hundred of them, and had also provided 2,500 loaves for the voyage. In all, two boat-loads seem to have left, carrying about one thousand of the refugees back to Ireland. ${ }^{6}$ There, to judge by James I's instruction of June $1606,{ }^{7}$ they were probably directed to some part of Munster - from which many of them had no doubt fled after Kinsale - where they re-settled as best they might.

\section{David Buisseret}

${ }^{4}$ See Gharles de La Roncière, Histoire de la marine Française (12 vols, Paris, 1899-1920), iv. 32 I.

${ }^{5}$ Registres des délibérations du bureau de la ville de Paris (i9 vols to date, Paris, I866-1958), xiv. 82-3.

${ }^{6}$ See The letters of John Chamberlain, ed. N. E. McClure (2 vols, Philadelphia, I939), i. 23 I.

${ }^{7}$ Calendar of state papers, Ireland, I6o3-6, pp. 496-8.

\section{Bellièvre to Henri IV, 2 November ${ }_{1605}$}

... Il se presente une affaire de tres grande importance, auquel jusques a present voz officiers n'ont sceu ni voulu pourveoir, quelques lettres de declaration qui leur en ayent esté envoyées et commandements qu'on leur ayt faictz de la part de Votre Majesté. Les Irlandais se trouvent en si grand nombre que le peuple de Paris n'en est pas seulement incommodé, mais aussi inquiet pour le mal qu'ilz peuvent faire la nuict aux personnes et maisons des particuliers. Le nombre des hommes est grand; il y a aussi nombre de femmes et petitz enfants qui se nourrissent mal et vivent si salement qu'ilz sont pour mectre la peste en la ville la plus saine de vostre royaulme. Il s'est parlé de les renvoyer en Angleterre, mais nous craignons et en sommes advertys qu'ilz ne seront pas admis pour la deffence qui y a esté faicte de n'y recevoir aulcun estranger qui n'ayt moyen de s'entretenir. Il 
semble par necessité qu'il faudra que vos ministres obtiennent du roy d'Angleterre que telz Irlandais qui seront envoyés de France seront receuz en Angleterre ou Irlande. Le secretaire de l'ambassadeur d'Angleterre m'a dit le remede qu'il juge le plus propre; est de renvoyer ces Irlandais avec leurs femmes et enfans jusques au Conques ${ }^{1}$ en Bretaigne, ou seroit escrit a monsieur de Sordeau ${ }^{2}$ de les fere porter en Irlande par mer, ce qui se pourroit du Conquest au premier part d'Irlande en deux jours. Au conseil qui a esté tenu en l'hostel de ville de Paris a esté advisé soubz le bon plaisir de Vostre Magesté qu'en ceste ville ilz contribueroient, pour la conduite de ces Irlandais jusques au premier part, la somme de mil ou deux mil escus, qui restent entre les mains du receveur des pauvres des deniers qui furent levés sur le peuple pour estre employés a subvenir aux malades de la peste, jugean que les deniers ne se peulvent mieux employer qu'en faisan sortir de la ville lesdits Irlandais qui necessairement y apporteront la peste s'ilz sejournent plus longuement. . . . ${ }^{3}$

\section{Bellièvre to Villeroy, 2 November ${ }_{1605}$}

... J'escry a Sa Majesté touchant les Irlandais que nous avons is Paris; les uns disent deux mil, les autres douze cens, tant y a que les rues en sont pleines. Si vous les chasses hors de Paris ilz feront beaucoup de mal aux pauvres gens des champs qui n'en sont que trop pleins. Il en vient de nouveau touts les jours; il fault deffendre en Bretagne de les recevoir aux navires qui commercent en Irlande pour l'achapt des peaulx de beufs. Il les fault fere conduyre en Bretagne soit de volunté soit par force. Le roy d'Angleterre ne peult avec justice refuser de y recevoir ceux qui sont ses subjectz. Quelques uns ont parlé de les renvoyer en Canada; monsieur du Mont qui en revient dict qu'il $z$ leur seroient inutiles et que pour rien il ne recevroit gens si inutiles et qui ne scavent et ne veullent travaigler. . . . ${ }^{4}$

${ }^{1}$ Le Conquet (Finistère) a few miles west of Brest.

${ }^{2}$ René de Rieux, sieur de Sourdéac, governor of Brest.

${ }^{3}$ MS fr. 15894, f. 609.

4 MS fr. I5578, f. 246 . 